\title{
Vitamin D deficiency and its associated comorbidities in very low birth weight neonates
}

\author{
Suresh Kumar Tripathy ${ }^{1}$, Soumini Rath ${ }^{1}$, Manas Kumar Nayak ${ }^{1}$, *Santosh Kumar Panda ${ }^{1}$
}

Sri Lanka Journal of Child Health, 2021; 50(3): 448-452

\begin{abstract}
Objectives: To assess the prevalence of vitamin D deficiency (VDD) and its associated co-morbidities among very low birth weight (VLBW) neonates.
\end{abstract}

Method: A prospective observational study was carried out at a tertiary care neonatal centre of Odisha, India, from February to November 2018. All VLBW infants admitted within the first 24 hours after birth were included in the study after parental consent. Infants with multiple congenital malformations were excluded. Initial blood samples were collected within the first 24 hours of life and vitamin D estimation was done by chemiluminescence immunoassay. Serum calcium and alkaline phosphatise (ALP) were measured by cresolphthalein complexone and para-nitro phenyl phosphate method respectively. Statistical Package for the Social Sciences version 16 was used for statistical analysis.

Results: Our study included 40 VLBW neonates with a mean birth weight of $1133.95 \pm 208.487 \mathrm{~g}$ and a mean gestational age of $30.60 \pm 2.274$ weeks. VDD prevalence was $67.5 \%$ and mean vitamin $\mathrm{D}$ level was $16.906 \pm 12.708 \mathrm{ng} / \mathrm{dl}$. However, the indirect laboratory parameters of VDD like mean serum calcium, phosphorous and ALP levels were within the normal range. There was higher incidence of respiratory distress syndrome (RDS) and sepsis in babies with VDD.

Conclusions: In this study VDD was found in $67.5 \%$ of VLBW babies. Incidences of RDS and neonatal sepsis were greater in babies with VDD.

DOI: http://doi.org/10.4038/sljch.v50i3.9694

${ }^{1}$ Kalinga Institute of Medical Sciences, KIIT University, Bhubaneswar, Odisha, India

*Correspondence: doc.sant@yahoo.co.in

iD https://orcid.org/0000-0003-0421-8747

(Received on 10 August 2020: Accepted after revision on 18 September 2020)

The authors declare that there are no conflicts of interest

Personal funding was used for the project.

Open Access Article published under the Creative

Commons Attribution CC-BY (c) (i) License
(Key words: Vitamin D deficiency, prevalence, comorbidities).

\section{Introduction}

Around 5-18\% of all deliveries are completed before 37 weeks and $4-8 \%$ of neonates are very low birth 'weight (VLBW) babies ${ }^{1}$. Vitamin D deficiency (VDD) is a known risk factor for osteopenia of prematurity $^{2}$. In northern India VDD prevalence in pregnant women is $93.5 \%$, whereas in southern India VDD prevalence is $61 \% \%^{3,4}$.

\section{Objectives}

To assess the prevalence of VDD and its associated co-morbidities among VLBW neonates.

\section{Method}

A prospective observational study was carried out in the neonatal intensive care unit (NICU) of Odisha, India, from February to November 2018. All VLBW infants admitted to the NICU in the first 24 hours after birth were included in the study. Infants with congenital malformations and infants whose parents denied consent for the study were excluded.

In all cases, a detailed history was taken giving due importance to maternal factors such as age, parity, history of gestational diabetes, hypertension, premature rupture of membranes, infection, medication like ante-natal corticosteroid therapy, obstetric complications like fetal distress, mode of delivery and natal history such as Apgar scores, resuscitation, birth weight and gestational age. Data were recorded in a predesigned proforma.

Within 24 hours of birth $3 \mathrm{ml}$ blood samples of the newborns were collected in two separate red topped vials (with clot activator), one for 25 hydroxy vitamin $\mathrm{D}[25(\mathrm{OH}) \mathrm{D}]$ and the other for alkaline phosphatase (ALP), total serum calcium and phosphorous. Vitamin D was estimated by the chemiluminescence immunoassay (CLIA) method. Serum calcium and ALP were measured by cresolphthalein complexone method and para-nitro phenyl phosphate method respectively. We considered $25(\mathrm{OH}) \mathrm{D}<20 \mathrm{ng} / \mathrm{mL}$ as VDD and $25(\mathrm{OH}) \mathrm{D}<10 \mathrm{ng} / \mathrm{mL}$ as severe VDD as per Holick $\mathrm{MF}$, et $a l^{5} ; 25(\mathrm{OH}) \mathrm{D}$ level between $21-29 \mathrm{ng} / \mathrm{mL}$ was considered vitamin D insufficiency and $25(\mathrm{OH})$ D level $\geq 30 \mathrm{ng} / \mathrm{mL}$ was taken as vitamin D sufficiency. 
Septic screen was done when there was a history of preterm premature rupture of membranes, maternal fever, foul smelling liquor, severe birth asphyxia with active resuscitation, prolonged labour or when babies presented with poor feeding, lethargy, respiratory distress, seizures, abdominal distension or bleeding. Appropriate culture specimens were obtained before initiating antibiotic therapy which was modified later on the basis of laboratory reports and response of the patient to treatment.

Under aseptic conditions about one $\mathrm{ml}$ of blood was drawn for septic screening and one $\mathrm{ml}$ for blood culture. One ml of blood was drawn and collected in culture bottle. Alcohol-Povidone Iodine-Alcohol was applied in consecutive steps. Povidone iodine was applied in concentric circles moving outwards from the centre and allowed to dry for at least 30 seconds. One $\mathrm{ml}$ of blood in 10-20 $\mathrm{ml}$ of broth or 0.5 $\mathrm{ml}$ of blood in $5-10 \mathrm{ml}$ broth was taken for blood culture. Leucopenia $(<5000 / \mathrm{cu} \mathrm{mm})$ or absolute neutropenia $(<1800 / \mathrm{cu} \mathrm{mm})$, band cell count of more than $20 \%$ or immature to total neutrophil (I/T) ratio $>0.2$ and C-reactive protein (CRP) of $>10 \mathrm{mg} / \mathrm{dl}$ constitute a useful septic screen for clinically doubtful cases. Two or more positive tests out of the above 5 were considered as a positive septic screen.

Lumbar puncture (LP) was done in suspected cases of late-onset neonatal sepsis or those having staring look, seizures and bulging fontanelle except when the infant was too sick to undergo LP. Cerebrospinal fluid (CSF) was inoculated for cytology and gram staining, biochemical analysis, and culture/ sensitivity. CSF cytology showing $>30$ white blood cells with $>60 \%$ polymorphs, glucose $<50 \%$ of blood glucose or $<40 \mathrm{mg} / \mathrm{dl}$, protein $>150 \mathrm{mg} / \mathrm{dL}$ in term babies and $180 \mathrm{mg} / \mathrm{dL}$ in preterm babies were diagnosed as meningitis. Midstream or catheterized urine was collected in a sterile container for routine examination. In suspected cases of inborn errors of metabolism, reducing sugar was especially looked for. For culture, suprapubic specimen was collected especially in girls and sent for culture / sensitivity. In babies who presented with respiratory distress, chest x-ray was done to look for radiological evidence of respiratory distress syndrome (RDS).

Ethical issues: Ethical clearance for the study was obtained from the Institutional Ethics Committee of the Kalinga Institute of Medical Science Hospital, Kalinga Institute of Industrial Technology University, Bhubaneswar, Odisha, India (No. KIMS/KIIT/IEC/83/2017). Written informed consent was obtained from the mothers of the neonates involved in the study.

Statistical analysis: Statistical Package for Social Sciences (SPSS) version 16 (Chicago, IL, USA) was used for statistical analysis and Chi-square test and unpaired t-test were used for comparison of descriptive characteristics between the groups.

\section{Results}

During the study period there were 415 admissions to the NICU, of which 63 were VLBW babies. Among the VLBW babies, 40 parents gave consent for the study. Our study thus included 40 VLBW neonates. The demographic profile of the study population is shown in Table 1 .

Table 1: Demographic profile of study population

\begin{tabular}{|l|c|}
\hline \multicolumn{1}{|c|}{ Characteristic } & Number $\mathbf{( \% )}$ \\
\hline Mode of delivery & $22(55)$ \\
Vaginal delivery & $18(45)$ \\
Caesarean section & $17(42.5)$ \\
\hline Sex & $23(57.5)$ \\
Male & $11(27.5)$ \\
Female & $29(72.5)$ \\
\hline Birth weight & \\
$<1000 \mathrm{~g}$ & $05(12.5)$ \\
$1000-1499 \mathrm{~g}$ & $21(52.5)$ \\
\hline Gestational age & $14(35.0)$ \\
$<28$ weeks & $0(0)$ \\
28 to $<32$ weeks & \\
32 to 35 weeks & $34(85.0)$ \\
$>35$ weeks & $06(15.0)$ \\
\hline Place of delivery & \\
Inborn & $25(62.5)$ \\
Outborn & $10(25.0)$ \\
\hline Antenatal steroid & $05(12.5)$ \\
Complete & \\
Incomplete & \\
None & \\
\hline
\end{tabular}

In our study $14(35 \%)$ neonates were born between 32 to 35 weeks of gestation. Of them $7(50 \%)$ had VDD $<20 \mathrm{ng} / \mathrm{ml}, 6(42.9 \%)$ having severe VDD $(<10 \mathrm{ng} / \mathrm{ml})$. The other $7(50 \%)$ had vitamin D levels $\geq 20 \mathrm{ng} / \mathrm{ml}$. The clinical characteristics of study subjects are shown in Table 2 .

Table 2: Clinical characteristics of study subjects

\begin{tabular}{|l|c|}
\hline \multicolumn{1}{|c|}{ Variables } & Mean (SD) \\
\hline Birth weight $(\mathrm{g})$ & $1133.95(208.487)$ \\
\hline Gestational age (weeks) & $30.60(2.274)$ \\
\hline Serum vitamin D (ng/ml) & $16.9055(12.708)$ \\
\hline Serum calcium $(\mathrm{mg} / \mathrm{dl})$ & $8.5278(0.807)$ \\
\hline Serum phosphorous $(\mathrm{mg} / \mathrm{dl})$ & $6.505(1.374)$ \\
\hline Serum alkaline phosphatase (U/L) & $202.8308(73.002)$ \\
\hline
\end{tabular}

The vitamin D status of the 40 neonates is shown in Table 3.

Table 3: Vitamin D status

\begin{tabular}{|l|c|}
\hline \multicolumn{1}{|c|}{ Vitamin D level } & n (\%) \\
\hline Severe vitamin D deficiency $(<10 \mathrm{ng} / \mathrm{ml})$ & $18(45.0)$ \\
\hline Mild vitamin D deficiency $(10-19 \mathrm{ng} / \mathrm{ml})$ & $09(22.5)$ \\
\hline Vitamin D insufficiency $(20-29 \mathrm{ng} / \mathrm{ml})$ & $07(17.5)$ \\
\hline Vitamin D sufficiency $(\geq 30 \mathrm{ng} / \mathrm{ml})$ & $06(15.0)$ \\
\hline
\end{tabular}


Table 4 is a comparison between infants with and without vitamin $\mathrm{D}$ deficiency. Though the mean serum vitamin D level was below normal value, the indirect biochemical parameters of vitamin D status, like mean serum calcium $(8.5278 \pm 0.80713 \mathrm{mg} / \mathrm{dL})$, mean serum phosphorous $(6.505 \pm 1.3744 \mathrm{mg} / \mathrm{dL})$ and mean serum ALP $(202.8308 \pm 73.00187 \mathrm{U} / \mathrm{L})$ were within the normal range (Table 2). However, gestational age or birth weight of babies did not have a significant association with VDD. Also no significant difference in serum calcium, phosphorous, ALP level was found between infants with or without VDD (Table 4).

Table 4: Comparison between infants with and without vitamin D deficiency

\begin{tabular}{|l|c|c|c|}
\hline \multirow{2}{*}{ Variables } & \multicolumn{2}{|c|}{ Vitamin D deficiency } & \multirow{2}{*}{ p-value } \\
\cline { 2 - 3 } & No & Yes & \\
\cline { 2 - 3 } & Mean \pm SD & Mean \pm SD & \\
\hline Gestational age (weeks) & $31.15 \pm 1.95$ & $30.33 \pm 2.40$ & 0.29 \\
\hline Birth weight $(\mathrm{g})$ & $1140.31 \pm 163.50$ & $1128.30 \pm 225.64$ & 0.86 \\
\hline Serum calcium $(\mathrm{mg} / \mathrm{dl})$ & $8.6015 \pm 0.7335$ & $8.4922 \pm 0.8514$ & 0.47 \\
\hline Serum phosphorous $(\mathrm{mg} / \mathrm{dl})$ & $6.575 \pm 1.809$ & $6.474 \pm 1.172$ & 0.83 \\
\hline Serum alkaline phosphatase $(\mathrm{U} / \mathrm{L})$ & $191.5800 \pm 68.1182$ & $207.8311 \pm 75.7723$ & 0.51 \\
\hline
\end{tabular}

The relationship of VDD with neonatal morbidities is shown in Table 5. Neonates with VDD had significantly higher incidence of RDS and neonatal sepsis. There was no significant association between the incidence of necrotising enterocolitis, bronchopulmonary dysplasia, retinopathy of prematurity and osteopenia of prematurity and neonatal vitamin D status at birth (Table 5).

Table 5: Relationship of vitamin D deficiency with neonatal morbidities

\begin{tabular}{|l|c|c|c|}
\hline \multirow{2}{*}{ Variables } & \multicolumn{2}{c|}{ Vitamin D deficiency } & \multirow{2}{*}{ p-value } \\
\cline { 2 - 4 } & No $(\boldsymbol{n}=\mathbf{1 3})$ & Yes $(\boldsymbol{n}=\mathbf{2 7})$ & \\
\hline Respiratory distress syndrome & 05 & 15 & 0.0253 \\
\hline Sepsis & 02 & 10 & 0.0209 \\
\hline Necrotising enterocolitis & 03 & 05 & 0.4795 \\
\hline Broncho-pulmonary dysplasia & 06 & 09 & 0.4386 \\
\hline Retinopathy of prematurity & 04 & 07 & 0.3657 \\
\hline Osteopenia of prematurity & 06 & 11 & 0.1452 \\
\hline
\end{tabular}

\section{Discussion}

This study was conducted to assess the prevalence of VDD among VLBW neonates and its associated co-morbidities. Low neonatal vitamin $\mathrm{D}$ was associated with low maternal vitamin $\mathrm{D}$ level in various studies 6,7 . In our study, $67 \%$ of VLBW neonates had VDD and $45 \%$ of babies had severe VDD. The mean birth weight and gestational age of VLBW neonates in our study were $1133.95 \pm 208.487 \mathrm{~g}$ and $30.60 \pm .274$ weeks respectively and the mean vitamin $\mathrm{D}$ level was $16.9055 \pm 12.70802 \mathrm{ng} / \mathrm{ml}$. Similar to our study, Chhina AS, et $a l^{8}$ analysed the $25(\mathrm{OH}) \mathrm{D}$ levels of preterm infants $<32$ weeks at $48-72$ hours, in Bangalore, India. The mean $25(\mathrm{OH}) \mathrm{D}$ level was $14.8 \pm 7 \mathrm{ng} / \mathrm{mL}$ and neonates born at $<28$ weeks had low vitamin D levels.

The prevalence of VDD in VLBW neonate at birth varied in many studies. The mean vitamin $\mathrm{D}$ level of VLBW neonate at birth was $16.906 \pm 12.708 \mathrm{ng} / \mathrm{ml}$ and the prevalence of VDD $98.9 \%$ and severe VDD $51.5 \%$ in the study by Park SH, et al ${ }^{6}$. In an Indian study by Jain $\mathrm{V}$, et $a l^{7}$, prevalence of VDD, severe VDD and vitamin D insufficiency were $66.7 \%$, $27.1 \%$ and $19.8 \%$ respectively $^{7}$. Naik KD, et al ${ }^{9}$ found the mean cord blood $25(\mathrm{OH}) \mathrm{D}$ level of term healthy neonates to be $11.36 \pm 4.75 \mathrm{ng} / \mathrm{mL}$ in Kerala, India ${ }^{9}$. The above study showed that neonatal VDD was also found in tropical climates. Due to financial constraints we could not evaluate the vitamin D status of mothers.

In this study, the mean serum calcium, phosphorous and ALP levels were comparable in infants with or without VDD at birth. In our study population, majority of neonates had VDD but the indirect biochemical parameters of vitamin D status like mean serum calcium, phosphorous, ALP were within the normal range. Hence indirect biochemical marker could not suggest the vitamin D status at birth. We found no positive correlation between VDD and birth weight. With subgroup analysis of our study, higher VDD was found among extremely premature $(<28$ weeks) infants. Several studies found that there was no correlation between vitamin $\mathrm{D}$ level and birth weight or gestational age $\mathrm{e}^{7,10,11}$.

We found that VDD was significantly associated with RDS and neonatal sepsis but had no significant association with bronchopulmonary dysplasia, osteopenia of prematurity, necrotizing enterocolitis 
or retinopathy of prematurity. Lung maturation is enhanced by vitamin D. Lipopolysaccharide induced alveolar inflammation and epithelial damage are aggravated by VDD. Boskabadi $\mathrm{H}$, et $\mathrm{al}^{12}$ and Gatera $\mathrm{VA}$, et $a l^{13}$ also reported a significant correlation between VDD and RDS. Vitamin D plays an important role in neonatal immunity. It regulates inflammation, chemokine production and immunomodulation. Nearly all immune cells like lymphocytes, monocytes and dendritic cells have vitamin D receptor (VDR). Vitamin D regulates neutrophil chemotaxis and phagocytic function. Vitamin D helps in improvement of immune function by production of antimicrobial peptides like cathelicidin and $\beta$ defensin from lymphocytes, monocytes and macrophages. Cathelicidin defends against micro-organism like bacteria, fungi and mycobacteria entry at various sites including skin, respiratory mucosa and gastrointestinal systems. Both peptides killed microbes by disrupting their cell membrane. Cetinkaya $\mathrm{M}$, et $a l^{14}$ and Cizmeci $\mathrm{MN}$, et $a l^{15}$ found early onset neonatal sepsis was higher in babies with VDD.

\section{Conclusions}

In this study VDD was found in $67.5 \%$ of VLBW babies. Incidences of RDS and neonatal sepsis were greater in babies with VDD.

\section{References}

1. Preterm birth Fact Sheet N 363. World Health Organization. Available at: URL: http://www.who.int/mediacentre/factsheets/f s363/en/; 2015.

2. Rustico SE, Calabria AC, Garber SJ. Metabolic bone disease of prematurity. Journal of Clinical and Translational Endocrinology 2014; 1(3): 85-91. https://doi.org/10.1016/j.jcte.2014.06.004 PMid: 29159088 PMCid: PMC5684970

3. Forrest KY, Stuhldreher WL. Prevalence and correlates of vitamin D deficiency in US adults. Nutrition Research 2011; 31(1): 4854.

https://doi.org/10.1016/j.nutres.2010.12.001 PMid: 21310306

4. Sharma S, Kumar A, Prasad S, Sharma S. Current scenario of vitamin D status during pregnancy in North Indian Population. Journal of Obstetrics and Gynaecology of India 2015; 66(2): 93-100.

https://doi.org/10.1007/s13224-014-0658-5 PMid: 27046962 PMCid: PMC4818828
5. Holick MF, Binkley NC, Bischoff-Ferrari HA, Gordon CM, Hanley DA, et al. Evaluation, treatment, and prevention of vitamin D deficiency: an endocrine society clinical practice guideline. Journal of Clinical Endocrinology and Metabolism 2011; 96: 1911-30.

https://doi.org/10.1210/jc.2011-0385

PMid: 21646368

6. Park SH, Lee GM, Moon JE, Kim HM. Severe vitamin D deficiency in preterm infants: maternal and neonatal clinical features. Korean Journal of Pediatrics 2015; 58(11): 427-33.

https://doi.org/10.3345/kjp.2015.58.11.427

PMid: 26692878 PMCid: PMC4675923

7. Jain V, Gupta N, Kalaivani M, Jain A, Sinha A, Agarwal R. Vitamin D deficiency in healthy breastfed term infants at 3 months \& their mothers in India: seasonal variation \& determinants. Indian Journal of Medical Research 2011; 133(3): 267-73.

8. Chhina AS, Shenoi A, Nagendra N, Rao N, RajaM. Vitamin D and metabolic bone parameters in preterm neonates. Indian Pediatrics 2016; 53:1023-4. https://doi.org/10.1007/s13312-016-0982-1 PMid: 27889736

9. Naik KD, Preetha R, Ramachandran AM, Nath D. Cord blood vitamin D levels of term neonates. Indian Pediatrics 2015; 52: 75-6.

10. Patel P, Pollock N, Bhatia J. Vitamin D and bone health in very low and extremely low birth weight infants. Journal of Clinical Nutrition and Metabolism 2017; 1(1).

11. Singh G, Brar HK, Malik S. Vitamin D levels in preterm and term neonates at birth. International Journal of Contemporary Pediatrics 2017; 4(1): 48-52. https://doi.org/10.18203/23493291.ijcp2016 4515

12. Boskabadi H, Mamoori G, Khatami SF, Faramarzi R. Serum level of vitamin D in preterm infants and its association with premature-related respiratory complications: a case-control study. Electron Physician 2018; 10(1):6208-14. https://doi.org/10.19082/6208 PMid: 29588821 PMCid: PMC5853995 
13. Gatera VA, Abdulah R, Musfiroh I, Judistiani RTD, Setiabudiawan B. Updates on the status of vitamin $\mathrm{D}$ as a risk factor for respiratory distress syndrome. Advances in Pharmacological Sciences 2018; 2018: 8494816.

https://doi.org/10.1155/2018/8494816

PMid: 30364026 PMCid: PMC6186338

14. Cetinkaya M, Cekmez F, Buyukkale G, Erener-Ercan T, Demir F, Tunc $\mathrm{T}$, et al. Lower vitamin D levels are associated with increased risk of early-onset neonatal sepsis in term infants. Journal of Perinatology 2015; 35(1): 39 https://doi.org/10.1038/jp.2014.146

PMid: 25102323

15. Cizmeci MN, Kanburoglu MK, Akelma AK, Ayyildiz A, Kutukoglu I, Malli DD, et al. Cord-blood 25-hydroxyvitamin D levels and risk of early-onset neonatal sepsis: a casecontrol study from a tertiary care center in Turkey. European Journal of Pediatrics 2015; 174(6): 809-15.

https://doi.org/10.1007/s00431-014-2469-1

PMid: 25504199 